\title{
Erratum to: Surgical technique and effectiveness of microendoscopic discectomy for large uncontained lumbar disc herniations: a prospective, randomized, controlled study with 8 years of follow-up
}

\section{Mohamed Hussein • Ashraf Abdeldayem •}

Mahmoud M. M. Mattar

Published online: 12 July 2014

(c) Springer-Verlag Berlin Heidelberg 2014

\section{Erratum to: Eur Spine J}

\section{DOI 10.1007/s00586-014-3296-9}

Any postal communications to the corresponding author should be sent to Zagazig University rather than to Tennessee University; his e-mail address remains as originally published.

The online version of the original article can be found under doi:10.1007/s00586-014-3296-9.

M. Hussein

Tennessee University, Memphis, USA

M. Hussein $(\bowtie) \cdot$ A. Abdeldayem - M. M. M. Mattar Department of Orthopedics and Traumatology, Surgery Hospital, 4th Floor, Zagazig University Hospitals and Faculty of Medicine, Zagazig University, Zagazig City,

Sharkiah 44519, Egypt

e-mail: m_hussien9@yahoo.com 